Bangladesh J. Bot. 47(4): 975-983, 2018 (December)

\title{
VOLATILE OIL PRODUCTION, PROLINE, PROTEIN AND DNA PROFILE IN THREE MEDICINAL PLANTS EXPOSED TO SHORT-TERM DROUGHT STRESS
}

\author{
Amal Fadl Abdelkader* and Hala Ragab Nosair \\ Department of Botany, Faculty of Science, Ain Shams University, 11355, Cairo, Egypt
}

Keywords: Mentha longifolia, Ocimum basilicum, Proline, RAPD-DNA, SDS-PAGE, Volatile oil

\begin{abstract}
This present work deals with monitoring some molecular aspects standing beyond the varied production of volatile oil in three medicinal plants (Ocimum basilicum, B, Mentha longifolia, M and Origanum majorana, O) after ten days of exposure to drought stress by using $250 \mathrm{mM}$ mannitol as a drought inducer. The results showed that proline has increased in all drought-stressed plants as compared to the control. Four protein bands (210, 70, 63 and $18 \mathrm{kDa}$ ) have disappeared in stressed B-plant, in addition to low molecular weight newly expressed protein bands (16-78 $\mathrm{kDa}$ ). The protein polymorphism has varied among the species and ranged from 16.66 to $54.54 \%$. RAPD-DNA technique indicated high similarity of genomic-DNA in stressed and unstressed plants. GC-MS screened intensive fluctuations within the pool of phytochemical compounds. The genomic DNA structure was generally stable under drought stress despite of new proteins expression which mediated the induction of chemical compounds with antioxidant property to cope with the drought stress.
\end{abstract}

\section{Introduction}

Drought is the serious agricultural problem been treated as salinity (Ludlow and Muchow 1990). Mannitol-mediates both drought and osmotic stresses and it has been experimentally utilized to find the cause of incident drought stress in plants (Moinuddin et al. 2012). Drought sensitivity is a case of both nutrient transport inhibition and reduction of leaf expansion, which subsequently led to reduction of shoot length and root dry weight due to physiological inhibition of cellular elongation and suppression of cell wall carbohydrate synthesis (Dastgheib et al. 1990, Neumann 1995 and Ullah et al. 2014). The progressive water deficit was found to accumulate proline intensively in ornamental plants (Yamada et al. 2005). Only a few reports revealed that protein was not affected in drought-stressed crop plants (Ullah et al. 2014), where in others, protein profile under drought stress exhibited synthesis, expression and accumulation of new protein bands (Cheng et al. 1993 Kamal et al. 2010). However, synthesis and production of volatile oil compounds in subjected-ornamental plants to drought stress are relatively droughtresistant processes (Popp et al. 2002).

Unlike fatty acids, essential oils enclose fragrance with unspecific chemical composition. They are industrial compounds used in cosmetics, perfumes, drink and as falvor (Sellar 2001). Drought alters the chemical composition of oil via varying contribution ratio of volatile components in particular genera (Petropoulos et al. 2007). Generally, the yield of essential oil decreases under drought stress; however, oil percentage is unaffected or even increased due to the presence of stress antioxidant compounds that assist plants against stress conditions. Essential oil increased under drought stress in Origanum maforanal, Origanum majorana (Rhizopoulou and

Authors for correspondence: E-mail: <amal.abdelkader@yahoo.com>. 
Diamantoglou 1991) and in Salvia officinalis (Bettaieb et al. 2008) and in Calendula officinalis L. (Rahmani et al. 2019). In critical cases, the essential oil diminishes due to drought effect on reducing shoot, leaf number and /or leaf area (Farahani et al. 2008). In addition, the leaf position whether plain or curly has not interfered with oil production under drought stress, although curly leaf in sparsely produces higher amount of essential oil compared to plain leaf. Camphor, B, 1,8cineole and thujona were the chemical components that increase in ratio during moderate drought stress (Moinuddin et al. 2012). The random amplified RAPD-DNA is a powerful, rapid, simple technique and consistent for a particular plant species regardless of its age or origin (Micheli et al. 1994). RAPD-DNA elucidates variance of genetic relationship upon plants breeding and

considered the molecular marker of phylogenic analyses of plants species. So far, this substantial protocol had clarified genetic diversity of endangered plants (Liu et al. 2007, Zheng et al. 2008). In addition, RAPD-DNA had potentially exploited for identification of medicinal and aromatic plants components (Um et al. 2001). Previous investigations viewed similarity of DNA sequence between varied mango species, due to the significant similarity of varied species in the primer's amplification sites (Cordeiro et al. 2006).

The present study was aimed at identifying short drought influence on volatile oil production, protein profile and genomic-DNA pattern in three medicinal plants grown for 10 days at the flowering stage with the drought stress induced by D-mannitol treatments.

\section{Materials and Methods}

Three aromatic and medicinal plants (65-day-old) at flowering stage, namely Ocimum basilicum L (B), Mentha longifolia L. (M), and Origanum majorana L. (O) were purchased from local market located at Kafr Hakeem, Giza, Egypt. They were grown in a mixture of sand and clay soil (1:1). The plants were divided into two sets: The first set was left to grow for 10 days using normal irrigation water and the second set of plants (BM, MM, OM) was irrigated for 10 days using D-mannitol solution (M, $250 \mathrm{mM}$ ). After the end of the experiment, the vegetative leaves were detached from the plants and used for extraction and estimation of protein and DNA-RAPD. Oven-dried leaves $\left(70^{\circ} \mathrm{C}\right)$ were utilized for proline and GC-MS analyses.

Determination of free proline was conducted in dry leaves detached from the normally grown, Ocimum basilicum (B), Mentha longifolia (M), and Origanum majorana (O) or drought-stressed plants using acidic ninhydrin flowing the method described by Bates et al. (1973).

For potential identification of the organic components present in the dried leaf powder of the three medicinal plants (basil, mint and origanum) grown normally or under drought stress, GC-MS analysis was performed on HP 6890 Gas Chromatograph fitted with an SGE BPX5 fused-silica capillary column $(15 \mathrm{~m} \times 220 \mu \mathrm{m} \times 0.25 \mu \mathrm{m})$ and coupled to a HP 5973 mass selective quadrupole detector. The derivatized extracts were inoculated through Merlin Microseal ${ }^{\mathrm{TM}}$. High pressure Septumin pulsed splitless mode (pulse pressure $17.6 \mathrm{Psi}, 325^{\circ} \mathrm{C}$ ). The column oven was programmed to be enhanced with an initial isothermal at $50^{\circ} \mathrm{C}$ for $2 \mathrm{~min}$. The temperature was increased with $10^{\circ} \mathrm{C}$ per min reaching $360^{\circ} \mathrm{C}$, and then remained at this temperature for $15 \mathrm{~min}$. Helium was a carrier constant gas controlled using $2.0 \mathrm{ml} / \mathrm{min}$ flow. The ion source was maintained at $230^{\circ} \mathrm{C}$, ionization and fragmentation were accomplished by electron impact $(70 \mathrm{eV})$. The mass filter was scanned between $\mathrm{m} / \mathrm{z} 50$ and 700 , with a scan rate of 2.29 scans per second. Sodium dodecyl sulfate-polyacrylamide gel electrophoresis (SDS-PAGE) was performed according to the method of Laemmli (1970), as modified by Studier (1973). Water-soluble proteins were extracted from leaves of the tested plants. Then protein fractionations were performed exclusively on vertical slab gel $(19.8 \mathrm{~cm} \times 26.8 \mathrm{~cm} \times 0.2 \mathrm{~cm})$ using the electrophoresis 
apparatus manufactured by Cleaver, UK. The images were captured by digital camera (Sony, made in japan) and transferred directly to the computer.

DNA was isolated from young leaves located at the apex of the shoot of the three medicinal plants: basil, mint and origanum according to the manufacture's manual of DNA isolation and extraction kit (Promega).

PCR amplification reaction was performed using selected five primers in $0.2 \mathrm{ml}$ PCR Eppendorf tube containing optimized mixture (40 ultotal volume) which consisted of master mix solisprimer $(8 \mu \mathrm{l})$, Metabion German $(2 \mu \mathrm{l})$ and Template DNA ( $2 \mu \mathrm{l})$ write the concentration then completed up to $40 \mu \mathrm{l}$ by nuclease-free water. Amplification was performed in a programmed thermo cycler as follows: initial denaturation at $94^{\circ} \mathrm{C}$ for $5 \mathrm{~min}$ (one cycle), followed by 35 cycles of annealing at $94^{\circ} \mathrm{C}$ for $1 \mathrm{~min}$, at $37^{\circ} \mathrm{C}$ for $45 \mathrm{sec}$, and and extension at $72^{\circ} \mathrm{C}$ for $45 \mathrm{sec}$ then final extension, $72^{\circ} \mathrm{C}$ for $7 \mathrm{~min}$ (one cycle), and finally holding at $4{ }^{\circ} \mathrm{C}$ until use. Agarose (1.2\%) was utilized for separating PCR products. It was placed in 1X TAE buffer and then boiled in microwave. Ethidium bromide (write the concentration) was added to the melted gel after the temperature became $55^{\circ} \mathrm{C}$.

Each experiment was repeated for three times and illustrated data are means of independent replicates from three separate experiments.

\section{Results and Discussion}

In the present study, three medicinal plants were subjected to short-term drought stress using $250 \mathrm{mM}$ of D-mannitol solution for 10-day-irrigation. The abrupt rise of proline level in all plants upon mannitol treatments (Fig. 1) manifests the generation of stress in these genotypes, as has been also reported by Ashraf and Foolad 2007. Proline biosynthesis occurred via regulation of some enzymes biosynthesis and degradation and via maintenance of membrane stability to sustain stress tolerance (Kishor et al, 2005). The polymorphism that contributed to high and low molecular weight proteins points to the metabolic variations under drought stress (Table 1). In mint and origanum genotypes, six and two new protein bands were expressed, respectively with no missing protein bands. Four of the six protein bands in mint, were of low molecular weight (45, 33, 32 and $16 \mathrm{kDa}$ ). In origanum, the low molecular weight expressed proteins were 87 and 18 $\mathrm{kDa}$. In basil, four protein bands have disappeared and two have appeared at low molecular weight (78 and $16 \mathrm{kDa}$ ) under stress (Fig. 2). These low molecular weight proteins which are stress proteins, may function to maintain osmotic homeostasis under stress, and are responsible for production of organic antioxidant (Kosakivska et al. 2008). Referring to DNA-RAPD technique (Fig. 3), the structure of the genomic DNA under drought stress was stable although undergo some variations upon the gene expression, presumably due to the non-hazardous effect of mannitol, and of the short stress exposure which was not enough to cause mutation or breakdown of the genomic DNA of the medicinal plants. Similar study on tobacco plants showed that the genomic DNA under abiotic stress led to the expression of 30 genes, among which 20 genes were defensive genes modified by methylation in relation to stress (Wada et al. 2004). In agreement, the varied chemical compounds pool between control and stressed plants (no illustrated data) confirms the protein banding modification is likely due to gene expression. B-data indicates the presence of 126 compounds at different RTs. Among the most predominant compounds:2-Propenoic acid (5.2 \%), Eucalyptol (3.8\%), 2-Bornanone (3.55), acetic acid, hydroxy[(1-oxo-2-propenyl)amino (3.17\%) and 2-isopropyl-5-methyl-9-methylene (1.74\%). Alternatively, the BM data detected the appearance of 129 compounds, with the predominant compounds: propenoic acid (5.93\%), neophytadiene (3.16\%), 9, 12, 15-Octadecatrienoic acid, (Z, Z, Z) - (2.84\%), n-hexadecanoic acid (2.26\%), Bis (2-ethylhexyl) phthalate (2.6\%) and eucalyptol (1.85\%). Linalool in B-plants (2.834\%) is predominant over BM-plants (0.9311\%). 


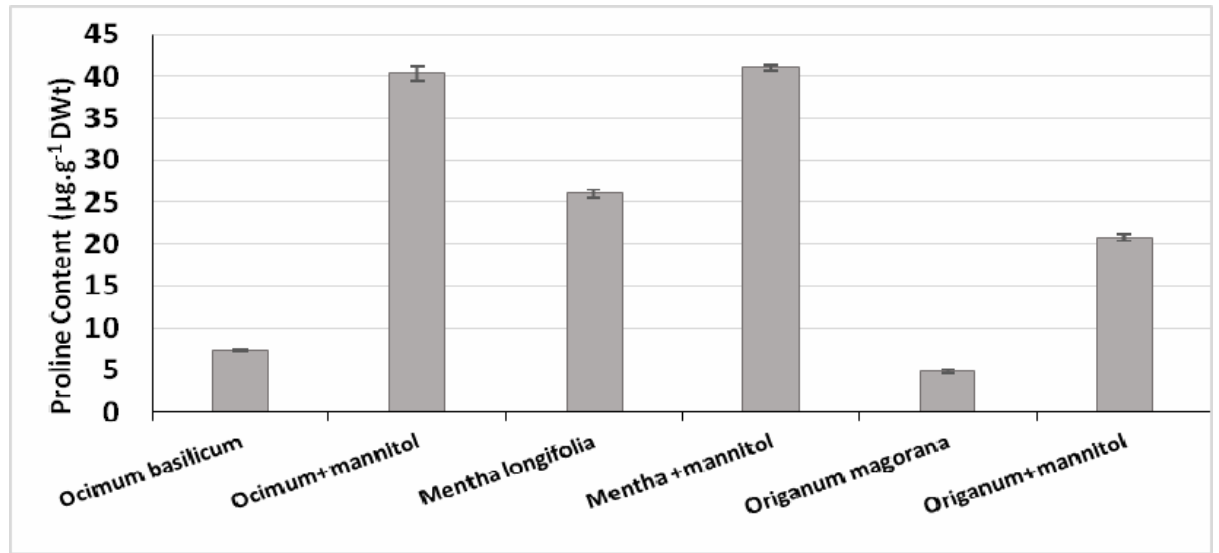

Fig. 1. Effect of D-mannitol treatments on the endogenous proline of the 65-days old medicinal plants (Ocimum basilicum, Mentha longifolia and Origanum magorana). Error bars designate to \pm SD of the mean.

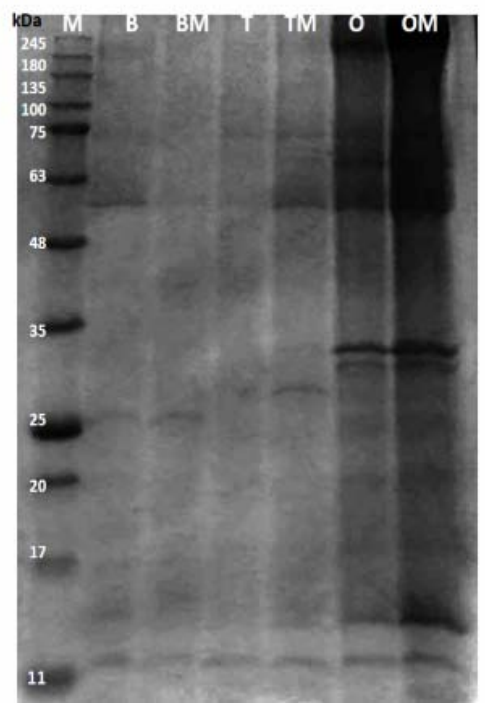

Fig 2. SDS-PAGE electrophoresis of the soluble protein extracted from apical leaves of some medicinal plants : basil (B), mint (T) and origanum (O) plants grown for 10 days either under normal irrigation condition using water or with irrigation using $250 \mathrm{mM}$ mannitol-induced drought stress (BM, TM and OM). M: protein marker 245, 180, 135, 100, 75, 63, 48, 35, 25, 20, 17 and $11 \mathrm{kDa}$ ).

GC-MS data of normal growing M-plants determined 146 chemical compounds, the most predominant compounds: (Z)6, (Z) 9-pentadecadien-1-ol (6.05\%), methyl 8,11,14heptadecatrienoate (3.75\%), hydroxyl [(1-oxo-2-propenyl)amino]-(3.26\%), n-hexadecanoic acid (3.05\%), D-carvone (2.5\%) and nonacosane (2.17\%). On the other hand, GC-MS data of mannitoltreated Menthe longifolia (MM) revealed the presence of 129 compounds, some of them exist with relatively high ratios : 1,2-propanediamine (6.26\%), n-hexadecanoic acid (4.9\%), 12octadecadienoic acid (Z,Z)- (4.3\%) and D-carvone (3.3\%). 
Table 1. Percentage of polymorphism of extracted soluble protein from leaves of drought stressed medicinal plants (Basil $+M$, Mint $+M$ and origanum $+M$ ) using mannitol $(250 \mathrm{mM})$ for 10-day irrigation compared to the control plants (Basil, Mint and Origanum).

\begin{tabular}{|c|c|c|c|c|c|c|c|c|}
\hline \multirow{2}{*}{$\begin{array}{l}\text { Band } \\
\text { No. }\end{array}$} & \multirow[b]{2}{*}{$\mathrm{Rf}$} & \multirow[b]{2}{*}{ MWt } & \multicolumn{6}{|c|}{ Medicinal plants } \\
\hline & & & Basil & Basil+M & Mint & Mint + M & Origanum & Origanim $+\mathrm{M}$ \\
\hline 1 & 0.043 & 230 & - & - & + & + & - & - \\
\hline 2 & 0.052 & 210 & + & - & - & - & - & - \\
\hline 3 & 0.058 & 190 & - & - & - & + & - & - \\
\hline 4 & 0.104 & 119 & - & - & - & + & - & - \\
\hline 5 & 0.115 & 110 & - & - & - & - & + & + \\
\hline 6 & 0.124 & 105 & - & - & + & + & - & - \\
\hline 7 & 0.147 & 87 & - & - & + & + & - & + \\
\hline 8 & 0.160 & 78 & - & + & - & - & - & - \\
\hline 9 & 0.175 & 70 & + & - & + & + & + & + \\
\hline 10 & 0.241 & 63 & + & - & + & + & + & + \\
\hline 11 & 0.271 & 60 & + & + & + & + & + & + \\
\hline 12 & 0.311 & 52 & - & - & + & + & - & - \\
\hline 13 & 0.329 & 49 & - & - & - & - & + & + \\
\hline 14 & 0.352 & 45 & - & - & - & + & + & + \\
\hline 15 & 0.372 & 42 & - & - & - & - & + & + \\
\hline 16 & 0.390 & 40 & + & + & + & + & + & + \\
\hline 17 & 0.408 & 38 & - & - & - & - & + & + \\
\hline 18 & 0.444 & 35 & - & - & - & - & + & + \\
\hline 19 & 0.481 & 33 & - & - & - & + & + & + \\
\hline 20 & 0.503 & 32 & - & - & - & + & + & + \\
\hline 21 & 0.546 & 29 & - & - & + & + & + & + \\
\hline 22 & 0.600 & 25 & + & + & + & + & + & + \\
\hline 23 & 0.629 & 23 & - & - & - & - & - & + \\
\hline 24 & 0.674 & 20 & + & + & + & + & + & + \\
\hline 25 & 0.702 & 19 & - & - & + & + & - & - \\
\hline 26 & 0.732 & 18 & + & - & + & + & - & + \\
\hline 27 & 0.816 & 17 & + & + & + & + & + & + \\
\hline 28 & 0.856 & 16 & - & + & - & + & - & - \\
\hline 29 & 0.881 & 15 & + & + & + & + & + & + \\
\hline 30 & 0.937 & 12 & + & + & + & + & + & + \\
\hline \multicolumn{3}{|c|}{ Band number } & 11 & 9 & 16 & 22 & 18 & 21 \\
\hline \multicolumn{3}{|c|}{ \% polymorphism } & - & 54.54 & - & 37.50 & - & 16.66 \\
\hline
\end{tabular}

GC-MS data analysis of chemical composition of normal growing Origanum majorana (O) elicited the presence of 114 compounds at different RTs. Some of these compounds are detected in high proportions: Hydroquinone (3.77\%), octadecanamide (3.28\%), hexacosane (2.7\%), nhexadecanoic acid (2.68\%) and 9, 12, 15-octadecatrienoic acid, (Z, Z, Z) - (2.55\%). On the other hand, the chemical composition obtained from GC-MS analysis of mannitol-treated origanum plants (OM) shows 118 compounds where 9,12,15-Octadecatrienoic acid, (Z, Z, Z) - (4.7\%), cyclobutanol (3.3\%), hydroquinone (2.87\%), 9-hexacosene $(2.6 \%)$ and n-hexadecanoic acid (2.58\%) were predominating. 

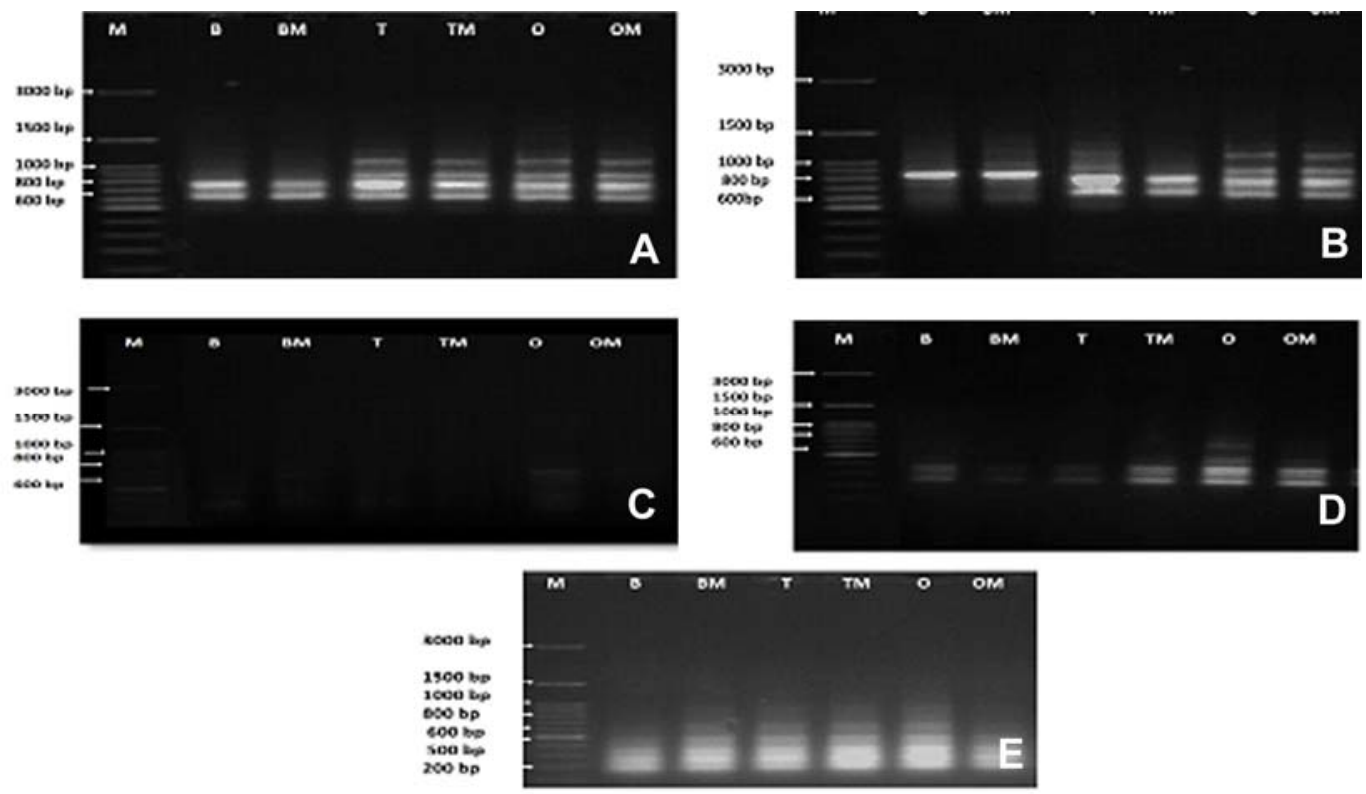

Fig 3. Agarose gel electrophoresis of RAPD-PCR amplification fragments as products obtained using five primers: (A; OPA-1, B; OPA-4, C; OPA-11, D; OPB-3 (not successful), E; OPB-10). The primers introduced to isolated DNA from medicinal plants grown for 10-day with or without drought stress: basil (B), stressed basil (BM), mint (T), stressed mint (TM), origanum (O) and stressed origanum (OM). M; DNA size marker (100-3000 b).

The biological activities of the detected chemical substances are summarized as follows: Ethylene oxide is an insecticide and antimicrobial compound used for disinfection (Lin et al. 2017). Cyclobutanol is an inhibitory substance to mushroom tyrosinase (Xie et al. 2016). Dimethyl aminomethyl and methylamine are famous corrosive substances to eye and skin (Kennedy 2014). Furfural is the collagen stabilizer (Lakra et al. 2014). Linalool is antifungal and insecticidal natural product (Nyasembe et al. 2012). Acetic acid possesses antibacterial and antifungal properties and acts effectively as inhibitor of carbohydrate metabolism and on solubilization of cell membrane lipid causing subsequent death (Kim et al. 2016). The successive compounds, Bicyclo [3.1.1] heptane (0.58\%) and epianastrephin $(0.12 \%)$ are biologically undefined substances. Eucalyptol is reported to kill infectious organisms and preventing their spread (Wydro and Szedfo 2016). Allyldiethylamine inhibits the activity of harmful organisms (Shagun et al. 2016). 2-propenoic acid is a powerful biocide (Danish et al. 1995). Pinocarvone functions as antioxidant, antibacterial and possesses other biological activities (Lima et al. 2012). Naphthalene induces oxidative stress in Trifolium plants (Huang et al. 2017). Myrtenol, is antiinflammatory flavoring compound (Gomes et al. 2017). Neophytadiene is a bioactive lipid component (Ahn et al. 2016). The tricosane is an antibacterial substance (Samadi et al. 2012), whereas hexacosane, is the potent antibacterial agent (Kotan et al. 2010). Squalane is unsaturated hydrocarbon and acts as antioxidant, skin hydrator, detoxifier and drug carrier (Kim and Karanediz 2012). Safrole acts as antifungal and considered carcinogenic compound (Yang et al, 2017). D-limonene, the insecticidal natural product (0.7564\%, (Nyasembe et al. 2012). D-carvone is a compound of volatile oil characterized by medicinal properties as antimicrobial (Jirovetz et al. 2003). 


\section{Acknowledgments}

The authors are thankful to Mr. Awad and Ms. Doaa for running the GC-MS samples.

\section{References}

Ahn HM, Kim SH, Hyun SH, Lim SR, Kim HY, Junsang O, Lee KM, Hong SJ, Cho BK, Lee H, Lee CG and Cho HK2016. Effects of the timing of a culture temperature reduction on the comprehensive metabolite profiles of Chlorella vulgaris. Journal of Applied Phycology 28: 2641-2650.

Ashraf M and R. Foolad R2007. Roles of glycine betaine and proline in improving plant abiotic stress resistance. Environmental and Experimental Biology 59: 206-216.

Bates LS, Waldren RP, and Teare ID1973. Rapid determination of free proline for water-stress studies. Plant and Soil 39: 205-209.

Bettaieb I Zakhams N Wannes WA Kchouk ME and Marzouk B 2008. Water deficit effects on Salvia officinalis fatty acids and essential oils composition. Scientia Horticulturae 120: 271-275.

Cheng Y, Weng J Joshi CP and Nguye HT 1993. Dehydration stress-induced changes in translatable RNAs in sorghum. Crop Science 33: 1397- 1400.

Cordeiro MCR, Pinto ACQ, Ramos VHV and Faleiro FG 2006. Identificação da origem genética de plântulas em sementes poliembriônicas de mangueira (Mangifera indica, l.) cv. Rosinha por meio de marcadores RAPD. Revista Brasileira de Fruticultura 28: 164-167.

Danish M, Alt HG, Badshah A, AliS, Mazhar M and N Islam N 1995. Organotin esters of 3-(2-furanyl)-2propenoic acid: their characterization and biological activity. Journal of Organometallic Chemistry 486: 51-56.

Dastgheib F, Andrews M, Field RJ and MH Foreman1990. Effect of different levels of mannitol-induced water stress on the tolerance of cultivated oat (Avena sativa L.) to didofop-methyl. Weed Research 30: 171-179.

Gomes BS, Neto BPS, Lopes EM, Cunha FVM, Araujo AR, Wanderley CWS, Wong DVT, Junior RC, Ribeiro RA, Sousa DP, Medeiros VR, Oliveira RCM and Oliveira FA2017. Anti-inflammatory effect of the monoterpene myrtenol is dependent on the direct modulation of neutrophil migration and oxidative stress. Chemico-Biological Interactions 273: 73-81.

Farahani A, Lebaschi H, Hussein M, Hussein SA Reza VA and Jahanfar D 2008. Effects of arbuscular mycorrhizal fungi, different levels of phosphorus and drought stress on water use efficiency, relative water content and proline accumulation rate of coriander (Coriandrum sativum L.). Journal of Medicinal Plants Research 2: 125-131.

Huang Y, Huang J, song Y and Liu H 2017. Use of selenium to alleviate naphthalene induced oxidative stress in Trifoliumrepens L. Ecotoxicology and Environmental Safety 143:1-5.

Jirovetz L, Buchbauer G, Stoyanova AS, Georgiev EV and Damianova ST. 2003. Composition, quality control, and microbial activity of the essential oil of long-time stored dill (Anethumgraveolens L.) seeds from Bulgaria. Journal of Agricultural and Food Chemistry 51:3854-3857.

Kamal AHM, Kim KH, Shin KS, Choi JS, Baik BK, T sujimoto H, Heo HY, Park CS and Woo SH 2010. Abiotic stress responsive proteins of wheat grain determined using proteomics technique. Australian Journal of Crop Science 4:196-208.

Kennedy GL2014. Ethylamine. Encyclopedia of toxicology (Third edition). 267-269.

Kishor PB, Sangam S, Amrutha RN, Laxmi PS, Naidu KR, Rao KRSS, Rao S, Reddy KJ, Theriappan P and Sreenivasulu N 2005. Regulation of proline biosynthesis, degradation, uptake and transport in higher plants: Its implications in plant growth and abiotic stress tolerance. Current Science 88: 424-438.

Kim SH, Yang YS and Chung M 2016. Effect of acetic acid treatment on isoflavones and carbohydrates in pickled soybean. Food Research International 81: 58-65.

Kim SK and Karanediz F 2012. Biological importance and applications of sqalane and squalane. Advances of Food Nutritional Research 5: 223-233. 
Kotan R1, Cakir A, Dadasoglu F, Aydin T, Cakmakci R, Ozer H, Kordali S, Mete E and Dikbas N 2010. Antibacterial activities of essential oils and extracts of Turkish Achillea, Satureja and Thymus species against plant pathogenic bacteria. Journal of the Science of Food and Agriculture 90: 145-60.

Kosakivska I, Klymchuk D, Negretzky V, Bluma D and Ustinova A 2008. Stress proteins and ultrastructural characteristics of leas cells of plants with different types of ecological strategies. Genetic and Applied Physiology 34: 405-418.

Laemmli UK 1970. Cleavage of structural proteins during the assembly of the head of bacteriophage T4. Nature 227: 680-685.

Lakra R, Kiran MS, Usha R, Mohan R, Sundaresan R and Korrapati PS 2014. Enhanced collagen stabilization by furfural. International Journal of Biological Macromolecules 65: 252-257.

Lima DK, Ballico LJ, Lapa RF, Goncalves HP, Souza LM, Iacomini M, Werner MF, Baggio CH, Pereira IT, Silva LM, Facundo VA and Santos AR 2012. Evaluation of the antinociceptive, anti-inflammatory and gastric antiulcer activities of the essential oil from Piper aleyreanum C. DC in rodents. Journal of Ethnopharmacology 142: 274-282.

Lin L, DaiY and Cui H 2017. Antibacterial poly (ethylene oxide) electrospun nanofibers containing cinnamon essential oil/beta-cyclodextrin proteoliposomes. Carbohydrate Polymers178: 131-140.

Liu P, Yang YS, Hao CY and Guo WD 2007. Ecological risk assessment using RAPD and distribution pattern of a rare and endangered species. Chemosphere 68: 1497-1505.

Ludlow MM and Muchow RC 1990. A critical evaluation of the traits for improving crop yield in waterlimited environments. Advances in Agronomy 43: 107-153.

Micheli MR, Bova R, Pascale E and Ambrosio ED 1994. Reproducible DNA fingerprinting with the random amplified polymorphic DNA (RAPD) method. Nucleic Acids Research 22: 1921-1922.

Moinuddin M, Masroor M, KhanA and Naeem M 2012. Drought stress effects on medicinal and aromatic plants and the possible stress amelioration by mineral nutrition. Medicinal and Aromatic Plant Science and Biotechnology 6: 69-83.

Neumann PM 1995. The role of cell wall adjustment in plant resistance to water deficits (Rev. Interpret.), Crop Science 35: 1258-1266.

Nyasembe VO, Teal PEA, Mukabana WR, Tumlinson JH and Torto B 2012 Behavioral response of the malaria vector Anopheles gambiae to host plant volatiles and synthetic blends. Parasites \& Vectors $\mathbf{5}$ : 234.

Petropoulos SA, Daferera D, Polissiou MG and Passam HC 2007. The effect of water deficit stress on the growth, yield and composition of essential oils of parsley. Scientia Horticulturae 115: 393-397.

Popp MP, Keisling TC, McNew RW, Oliver LR, Dillon CR and Wallace DM 2002. Planting date, cultivar, and tillage system effects on dryland soybean production. Agriculture Journal 94: 81-88.

Rahmani N, Daneshian J and Farahani AH 2009. Effects of nitrogen fertilizer and irrigation regimes on seed yield of calendula (Calendula officinalis L.). Journal of Agricultural Biotechnology and Sustainable Development 1: 24-28.

Rhizopoulou S and Diamantoglou S 1991. Water stress induced diurnal-variations in leaf water relations, stomatal conductance, soluble sugars, lipids and essential oil content of Origanummaforanal. Jour. of Horticultural Science 66: 119-125.

Samadi N, Manayi A,Vazirian M, Samadi M, Zeinazadeh Z, Saqhari Z, Abadian N, Mozaffarian VO and Khanavi M 2012. Chemical composition and antimicrobial activity of the essential oil of Anthemisaltissima L. var. altissima. Natural Product Research 26: 1- 4.

Sellar W 2001. The Directory of Essential Oils (Reprint ed.). Essex: The C.W. Daniel Company, Ltd. ISBN 0-85207-346-1.

Shagun S, Sujata B and Manjul S 2016. Chemical profiling, antioxidant and antibacterial properties of Cotinus coggygria essential oil from wester himalaya. International Journal of Pharmacognosy and Phytochemical Research 8: 1183-1186.

Studier FW 1973. Analysis of bacteriophage T1 early RNAs and proteins of slab gels. Journal of Molecular Biology 79: 237-248. 
Ullah I, Akhtar N, Mehmood N, Shah IA and Noor M 2014. Effect of mannitol induced drought stress on seedling traits and protein profile of two wheat cultivars. The Journal of Animal \& Plant Sciences 24:1246-1251.

UmJ Y, Chung HS, Kim MS and Na HJ 2001. Molecular authentication of Panax ginseng species by RAPD analysis and PCR-RFLP. Biological and Pharmaceutical Bulletin 24: 872-875.

Wada Y, Miyamoto K and Kusano T 2004. Association between up-regulation of stress-responsive genes and hypomethylation of genomic DNA in tobacco plants. Molecular Genetics and Genomic 271: 658-666.

Wydro-KHLC and Szydfo K 2016. The influence of environmentally friendly pesticide Eucalyptol alone and in combination with terpinen-4-01 on model bacterial membranes. Colloids and Surfaces B: Biointerfaces 146: 918-923.

Yang AH, Zhang L, Zhi DX, Liu WL, Gao X and He X 2017.Identification and analysis of the reactive metabolites related to the hepatotoxicity of safrole. Xenobiotica 22: 1-9.

Yamada M, Morishita H, Urano K, Shiozaki N, Yamaguchi-Shinozaki K, Shinozaki K and Yoshiba Y 2005. Effects of free proline accumulation in petunias under drought stress. Jour. of. Experimental Botany 56:1975-1981.

Xie J, Dong H, Yu Y and Sao S 2016. Inhibitory effect of synthetic aromatic heterocycle thiosemicarbazone derivatives on mushroom tyrosinase: Insights from fluorescence, ${ }^{1} \mathrm{H}$ NMR titration and molecular docking studies190:709-716.

Zheng W, Wang L, Meng L and Liu J 2008. Genetic variation in the endangered Anisodustanguticus (Solanaceae), an alpine perennial endemic to the Qinghai-Tibetan Plateau. Genetica 132: 123-129. 